\title{
Sociolinguistic Influences on the Quality of Interpreting for Foreign African Immigrants in South African Courtrooms
}

\author{
Sam Erevbenagie Usadolo ${ }^{1}$ \\ ${ }^{1}$ Department of Communication, University of Fort Hare, Alice, South Africa \\ Correspondence: Sam Erevbenagie Usadolo, Department of Communication, University of Fort Hare, Alice, \\ South Africa. E-mail: usadolo1@yahoo.com
}

\author{
Received: October 5, 2015 Accepted: December 15, 2015 Online Published: January 31, 2016 \\ doi:10.5539/ijel.v6n1p13 URL: http://dx.doi.org/10.5539/ijel.v6n1p13
}

\begin{abstract}
The study presents some sociolinguistic influences on the quality of interpreting for foreign African immigrants in South African courtrooms. Data was collected using observation of courtroom proceedings and unstructured interviews. The sociolinguistic influences identified can be linked to factors such as the notion of equivalence, misunderstandings about the role of the interpreter by principal actors, code-switching, and interpreting in the first person and third person by interpreters. These factors are discussed in terms of their negative influences on the quality of interpreting and how they can be mitigated. Finally, based on the identified limitation of the study, suggestions for further study are given.
\end{abstract}

Keywords: code-switching, interpreting, linguistic rights, notion of equivalence, terminology

\section{Introduction}

In the South African Constitution (1996), the needs and rights of people using indigenous languages that were previously marginalised are recognised. These indigenous languages are isiXhosa, Sesotho, isiZulu, Sesotho sa Leboa (or Northern Sotho), isiNdebele, Setswana, Tshivenda, Xitsonga and SiSwati and are now accorded official status in this legislation in addition to the two dominant official languages-English and Afrikaans (South African Constitution, 1996: sections 6, 30 \& 31). This has been done to ensure that the linguistic human rights of the users of these marginalised languages are protected. According to Erasmus (1999, p. vii), "[I]f linguistic human rights are not respected, minorities and marginalised groups cannot truly participate in negotiations concerning their own fate". Erasmus advises that in order to maintain linguistic rights in a multicultural society such as South Africa, the services of translators and interpreters should be made available to facilitate communication between diverse linguistic groups. This is because when linguistic human rights are not acknowledged, most other rights that have been violated will remain violated, because the person whose rights have been violated will lack the linguistic capacity to express himself or herself (Usadolo \& Kotze, 2015).

Linguistic human rights, in the context of court interpreting, are very important, because they provide a vehicle through which accused persons are able to express themselves in defence of their other rights that may have been violated. The requirements which indisputably constitute linguistic human rights are clearly inviolable and sacrosanct features of the democratic basis of the Republic of South Africa, i.e. its Constitution (Usadolo \& Kotze, 2015). It is therefore important that such rights be honoured in respect of speakers of the official indigenous African languages and, by extension, in respect of immigrant communities (cf. Section 9(3)), by means of quality interpreting in courtrooms.

The courtroom is considered to be a sensitive social institution, because matters that come before it sometimes mean the difference between freedom and captivity, or, in some countries, life and death. This underscores the need for effective communication between participants in the courtroom, a need which is echoed by Khoon $(1990$, p. 110), who advises that all communication in court should be handled cautiously, because "any misrepresentation, be it even a verbal slip, may have dire consequences, particularly in cases where the fate of a defendant hangs in the balance". In this regard, Hewitt (1995) remarks that the provision of competent interpreters is important to guarantee linguistically disadvantaged individuals similar rights and access to justice as people who are native speakers of the languages used in the courtroom. In addition, effective communication made possible by interpreter, will help to fulfil the stipulation of the South African Constitution, which states that, "Every accused person has a right to a fair trial, which includes the right to be tried in a language that the 
accused person understands; or, if that is not practicable, to have proceedings interpreted in that language" (South African Constitution, 1996: section 35, 3(k)). Linguistic rights as described above are inclusive of all South Africans and immigrants who appear before the courts and cannot speak or write the main languages used during court proceedings.

The dawn of democracy in South Africa and its unique economic advantages have resulted in immigration situation that brings many immigrants across Africa into South Africa. Common among these nationals are immigrants from African countries, such as Zimbabwe, Botswana, Malawi, Lesotho, Malawi, Zambia, Mozambique, Nigeria and Ghana who are in South Africa as workers, tourists or refugees. My observation of courtroom proceedings during this study showed that a day hardly passes without foreign immigrants who are language-handicapped being arraigned in court. Many of these immigrants do not understand the two main official languages used in formal settings such as government departments and courtrooms. In order to meet the stipulation of the Constitution (South African Constitution, 1996: section 35, 3(k)), which expressly stresses the need to bridge language barriers and the need for linguistic human rights, the question of the provision of court interpreters is also extended to these foreign immigrants. In other words, the provision of court interpreters to foreign Africans will ensure that their language rights are recognised and their voices are heard during the legal process.

The focus of this study is on foreign African court interpreters who are engaged by the Department of Justice and Constitutional Development (DoJCD) in South Africa to interpret for foreign African immigrants. Besides foreign African court interpreters, there are local language court interpreters. They are referred to as local language court interpreters in this study because they interpret for accused persons or plaintiffs who speak indigenous South African languages such as isiXhosa, Sesotho, isiZulu, Sesotho sa Leboa (or Northern Sotho), isiNdebele, Setswana, Tshivenda, Xitsonga and SiSwati. Most of the interpreters in this category are employed by the DoJCD as permanent interpreters, as opposed to foreign African court interpreters who are employed on a casual basis. As they are permanent employees, they are exposed to career development in the form of training and also have a sense of job security. None of these characteristics apply to foreign African court interpreters.

Given the emphasis of the South African constitution on language rights, it needs to be seen whether the court systems are responding by ensuring the language rights of South Africans whose languages were marginalised in the past, and the language rights of the increasing numbers of immigrants in the country, are upheld. The central focus of the study is to examine how foreign African interpreters are responding to some of the sociolinguistic issues that affect the way they interpret in courtrooms. The method used to gather the data analysed in this study will be explained and relevant literature in court interpreting will be reviewed. The review will focus on issues such as how the quality of interpreting has been addressed and also the literature on foreign African interpreters. Following this will be analysis of the data categorised in different themes. The last section ends with discussion and conclusion to the study.

\section{Literature Review on Quality Interpreting in South Africa}

Very little scholarly research is available that focuses on foreign African interpreters in South African courtrooms. One of the leading scholars who has been concerned about the dearth of research in this area is Moeketsi (1999) who looks at interpreting in South Africa and suggests how the question of court interpreting can be redefined in order to ensure that it meets its desired objectives. Moeketsi points out several instances where the quality of interpreting has been compromised and suggests that addressing these problems will amount to a redefinition of the court interpreting landscape in South Africa. Some of the instances cited in her work involve: vested interests when interpreters are assigned to interpret for their relative, the absence of a clear role boundary between the interpreters and other actors in the court, frequent cases of amplification, charge sheets that contain Latin and French jargon, and pronouncements with complicated syntactic structures that are hurriedly read by the prosecutors. She (Moeketsi, 1999) refers to these as challenges that have to be mitigated so as to establish a court interpreting practice that addresses the concerns of those it is intended to serve. Further to this, Moeketsi \& Wallmach (2005) argue that in order to raise the quality of court interpreting, the level of education of the interpreter has to be taken into consideration. This led to a joint development of a Bachelor's Degree in Court Interpreting by Moeketsi \& Wallmach (2005) to respond to the failure of the DoJCD, and to the general low esteem in which court interpreting is held. In their article written about the development of the degree, they stress that there is a correlation between sound court interpreting education and quality in the practice of court interpreters. As such, they discuss the rationale behind the degree and its structures to point out how they think the problem of poor interpreting can be eliminated (Moeketsi \& Wallmach, 2005).

Following the work of Moeketsi \& Wallmach (2008) is another seminal piece that addresses the question of 
quality in court interpreting by Moeketsi \& Mollemma (2008). Taking a philosophical position, they argue that quality interpreting should be foregrounded on perfect interpreting practice (PIP) in order to have a system where practical methods are used to "ensure quality interpreting service consistently meets the needs of the customer and achieves continuous improvement in every aspect of the service" (Moeketsi \& Mollema, 2008, p. 30). In their argument for PIP, they state that a holistic approach where, among other conditions, interpreters are readily available if needed, with the observance of applicable standards and statutory requirements such as taking oath before proceedings to affirm the capacity of the interpreter. They also emphasise the need to institute a Court Interpreting Act that will make it mandatory to have a master list of certified interpreters, a schedule of fees, a mode of interpreting at different phases of the court proceedings, and the availability of different appropriate equipment. The question of role boundaries mentioned in Moeketsi (1999) is stressed again by Moeketsi \& Mollema (2008) in their call for mandatory training so that the main actors such as lawyers, prosecutors and magistrates or judges understand each other's roles in court interpreting. Usadolo \& Kotze (2010) support Moeketsi's (1999) findings about vested interests, although their study focuses on foreign African court interpreters. Based on their observation of foreign African court interpreters in courtrooms, they (Usadolo \& Kotze, 2010) point out several instances of vested interests and conflicts of interest as interpreters were seen playing an advocacy role, coaching accused persons and sometimes saying something completely different from what the accused has said in order to help the accused persons win their cases. In their work, they point out that this amounts to flagrant abuse by the interpreter of their position in the court-to which the interpreters in their study admitted but they did not care as they had evidence of open displays of racism, hatred and collusion on the part of the court trio (i.e. the magistrate, the prosecutor and the defence lawyer). Similarly, Inggs (1998) reports that in South African courts, interpreters admit to having the role of advocacy but regard this as a fundamental part of their work, even though it is very unethical. Both Usadolo \& Kotze's (2010) and Inggs' (1998) studies point to gross unethical practice made possible by a failure to regulate interpreting.

The study by Usadolo \& Kotze (2014) is unique in its focus on interpreters for foreign Africans in South African courtrooms. They discuss the inter-lingual communication challenges faced by foreign African court interpreters in the courtroom by looking at factors such as bilingualism, dialect usage, biculturalism and the requirement of sight translation in court. Given the data analysed, they point out that bilingualism is a challenge to foreign African court interpreters, as they may not have the balanced bilingualism required to interpret interlingually, even when they are employed on the basis of their professed bilingualism, with no measure put in place to ascertain their level of bilingualism. On this note, Usadolo \& Kotze remark that quality interpreting requires more than just balanced bilingualism; it requires relevant cultural and forensic knowledge. Their argument considers Mikkelson's (1999) remark in this instance that it is not just about inter-lingual requirements that enable one to substitute one term for another: a concept in one culture may not exist in another, and so an interpreter must be able to use a descriptive phrase to convey the idea satisfactorily. In the same work, Usadolo \& Kotze (2014) discuss the phenomenon of dialect and the daily difficulties it presents to foreign African court interpreters. The data discussed in their study regarding dialect show that the interpreters do not have the dialect levelling required to interpret in court. The same is true of biculturalism, and according to the data analysed some interpreters do not have cross-cultural knowledge because they have not lived in the linguistic community long enough to be able to know the community's culture thoroughly. Cross-cultural knowledge is fundamental to successful court interpreting practice because its lack will result in the interpreter not fully grasping the salient cultural features and, according to Liu (1994, p. 311) interpreters may have ideological inclinations that "lead to differences in logical thinking, and consequently different responses".

Lebese (2014) examines four legal documents, one of which is the Personnel Administration Standard (PAS) and none of them mentions the norms which court interpreters have to follow in their work. Hence, according to Lebese (2014, p. 202) instances "where court interpreters would ask their own questions, omit certain information, and add information that was never uttered by the speaker" are common. The PAS recognises the role of court interpreters in facilitating communication between the accused or plaintiff and others who understand the language of the court, but there is no mention of the norms the interpreter has to abide by, resulting in a situation where the interpreters are asking questions or explaining certain things that are supposed to have been asked or explained by magistrates (Lebese, 2014).

Another important legal document referred to in Lebese's (2014) study to explain how the question of quality is compromised is the Magistrates' Court Act. Lebese argues that while the Act regulates proceedings in the lower courts, defines the duties of various court officials, and mandates the magistrates to provide court interpreters for court participants who do understand the language used during court proceedings, it is silent in terms of guidelines in areas such as required qualifications to work as interpreter, level of language proficiency and 
regulatory measures.

Usadolo \& Kotze (2015) examine further the issues of quality interpreting by examining the challenges posed by cross-border languages on foreign African court interpreting practices. Among the languages observed in the study are Chisena, spoken in Mozambique, Malawi and Zambia, and Afrikaans, spoken widely both in South Africa and Namibia. They point out that the interpreters may not be adequately informed about the prevailing socio-cultural issues in the home country of the accused, especially when the accused is from a Lusophone country and the interpreter from an Anglophone country. Another potential challenge identified in this regard is different orthographies used for the Malawian and Mozambican varieties of Chisena. The two varieties have words which are phonetically similar, but are spelled differently, and this may be a challenge to the interpreter. They emphasise that court interpreters should be well-informed about relevant circumstances in the countries in which the cross-border languages are spoken, and argue that the interpreter should conduct a pre-trial interview with the accused in order to be able to interpret from the source language (SL) into the target language (TL).

The works reviewed so far discuss the quality of interpreting but none of these studies focused on the quality of interpreting for foreign African immigrants in South Africa, except for Usadolo \& Kotze (2010), Usadolo \& Kotze (2014), Usadolo \& Kotze (2015) which look at how foreign African interpreting from interlingual and cross-border language perspectives. The present study is an extension of the three studies mentioned. It highlights some sociolinguistic difficulties which can compromise the quality of interpreting for foreign Africans by court interpreters in South Africa.

\section{Method}

The data were collected from unstructured interviews that lasted between 15 and 20 minutes, and from information documented following my observations of proceedings in open courtroom sessions. The observations of court proceedings enabled me to identify some of the reported sociolinguistic challenges faced by foreign African court interpreters.

All foreign African court interpreters (from all countries in Africa), the magistrates, prosecutors, attorneys and managers of court interpreters (chief interpreters) in South Africa constituted the target population for the investigation. For a comprehensive study, it would have been necessary to collect data from every single member of the population. As this was demonstrably not possible, the study had to be based on a statistically justifiable representative sample of the population and generalised to the entire population. Sampling for a purpose such as this, as stated by Walliman (2006, p. 75), is, in essence, simply a 'process of selecting just a small group of people from a large group'.

In this study, the sample selected comprised 30 foreign African court interpreters from 10 African countries, and consisted of three each from Namibia, Nigeria, Zambia, Zimbabwe, Ghana, Mozambique, Malawi, the Democratic Republic of the Congo (DRC), Tanzania and Somalia, working in the Central Johannesburg, Germiston and Hillbrow Magistrate Courts in Johannesburg, South Africa. A total of 10 magistrates, 10 prosecutors and 10 attorneys were also participants in the study. Each Magistrate's Court has a chief interpreter, whose primary duty is to employ interpreters and to see that interpreters are assigned to cases that require interpreting. No sampling was done in the selection of chief interpreters, which means that all the chief interpreters in the courts mentioned were respondents in this study.

The foreign African court interpreters who were participants in this study had worked between 6 and 10 years as non-permanent members of staff of the DoJCD of South Africa. The data used in this article were taken from a pool of data collected for a broader study of court interpreting in the Magistrate's Courts mentioned above. Analysis of data collected through unstructured interviews and observation of court proceedings was aimed at identifying major themes or categories for investigation. From these categories or themes, the data that reflected the issues discussed in the next section were further analysed.

\section{Data Analysis}

In this section, the data collected and categorised into different themes will be analysed. The data has been categorised as relating to 1) the notion of equivalence, 2) misunderstandings about the role of interpreter and interpreting, and 3) code-switching, and interpreting in first person and third person.

\subsection{The Notion of Equivalence}

Although the notion of equivalence appears contentious, there is a consensus that equivalence is maintained when the content and intention behind what is said in the SL is reflected in the TL. The objective of court interpreting, therefore, is to provide an interpreter who will make sure people who do not have a common language communicate successfully with each other, maintaining the complete intent of the communication 
conveyed (AUSIT Code of Ethics and Conduct, 2012). The task of interpreting is made easier when a word or phrase in the SL has an equivalent in the TL. This prevents circumlocution, which interpreters sometimes resort to in order to interpret some English words in an African language. When interpreting English into many African languages, some English words do not have direct equivalents. The same applies to the task of finding equivalents of certain African words in English. For instance, I observed a court proceeding in Johannesburg Magistrate Court where the term human right posed a challenge to an Edo-speaking interpreter. He could not provide a direct equivalent in the Edo language, or a word or words with the same force of meaning in the TL. While the concept of a basic right is applicable in all societies in terms of fairness and equality, the idea is better expressed in the English worldview than in the Edo worldview.

In order to interpret human right into Edo, the interpreter had to resort to a sentence-long construction or circumlocution, or a phrase such as ẹtin n'okhẹke omwan ('power that is appropriate for one'). A direct equivalent of human right from English into Edo will read as evbin noma oghe emwanagbon. Although the phrase etin n'okhẹke omwan is usually the preferred equivalent, it does not satisfy what Nida $(2004$, p. 163) refers to as the "highest degree of approximation" that dynamically provide equivalence appropriate for the standard required in court interpreting. I observed that this particular interpreter, who in most cases, had to go further after rendering the term human rights into Edo by giving examples of different types of human rights to ensure that the accused person understood the meaning of the term. Two other Edo-speaking interpreters I interviewed to find out how they would interpret 'human rights' as an SL into Edo as a TL also went through a process of circumlocution in interpreting the term. One of them said he would always just leave 'human rights' as it is because it is a common concept everybody understands. This interpreter's response is consistent with my observation in Johannesburg Magistrate Court. On 6 August 2009, I observed some cases in Johannesburg Magistrate Court (Court 5) where the interpreter left the term as it was, as an intrasentential switch, and would then ask the accused whether he/she understood the meaning of the expression in the context in which it was used. My interviews with these interpreters uncovered the fact that they came across the need to interpret this term (human rights) regularly into the Edo language. One would have thought that this would prompt them to consult other interpreters and academics and then settle on the best equivalent in the TL. According to Mikkelson (1995) the preferred course of action to take in this regard is to conduct parallel research about what could possibly be the best equivalent term or phrase in the TL by gathering a number of potential terms or phrases and then deciding which one comes closest in conveying the meaning of the English term.

Interpreting in general, and court interpreting in particular, takes place in an unpredictable situation where there is no certainty about the terms or phrases that one will encounter. It is for this reason the AUSIT Code of Ethics \& Conduct (2012) advises interpreters to commit themselves to life-long learning, as interpreting situations evolve and change over time and they need to seek contextual and cultural understanding. Mikkelson (1995) and the AUSIT Code of Ethics \& Conduct (2012) provide advice for what experienced interpreters who are concerned about the quality of their services to their clients should do, as they may have equivalent words or terms, or a particular way in which they interpret human right in their repertoire so that they do not have to struggle to find an equivalent. In other words, interpreters are likely to encounter problems in finding equivalents for new words or terms, but for interpreters with experience who are concerned with the quality of their service, this should not be a problem.

However, based on the data analysed for this study, it is clear that foreign African interpreters seldom if ever conduct terminology research and it is not considered a challenge for the court interpreters' systems. A significant number of the foreign African interpreters $(\mathrm{N}=24)$ across most of the languages represented in this study agreed that they do meet with challenges in finding equivalent terms in the TL but they haven't deemed it necessary to do terminology research. To quote one of the interpreters whose view is similar to those of the other interviews:

We do meet with the vexed question of terminological equivalence and find a way around it. To the best of my knowledge, no colleagues of mine have told me this has led them to research of any kind. Look, we are casual even though some of us have been doing this job for more than eight years. Uncertainty about our job does not really help in going out there to start doing research when at the whim of my boss I can be asked to stop work anytime. So why research?

Finding equivalent terms or phrases with the "highest degree of approximation" and retaining the complete intent of the communication is a common challenge for interpreters. It is not surprising as they are not expected to find every term in their reference materials when a terminology challenge arises. Given the excerpt above, it is, however, strange that the challenges that occur in this regard are not dealt with by interpreters in order to mitigate its future occurrence by becoming skilful at terminology research, and having access to good reference 
materials to guarantee quality court interpreting. Interpreting scholars recognise that there are terminology challenges in interpreting and they advise interpreters to make sure they acquire terminologies across all the domains they encounter (Seleskovitch, 1978; Frishberg, 1986; Gonzalez, Vásquez, \& Mikkelson, 1991).

Although the reluctance to do terminology research expressed by the interpreter in the excerpt above is inexcusable, it may help to point out one glaring fact. The interpreter mentioned that they are casual or ad hoc interpreters with no guarantee of job security, and hence it was pointless to do terminology research as they see that as a function of permanently employed interpreters. The fact that foreign African interpreters are employed as casuals in South Africa is not surprising because the same situation applies to court interpreting authorities in many other jurisdictions (See Gonzales et al., 1991; Miguélez, 1999). However, the South African scenario needs to be understood in the context of the fact that a significant percentage of interpreters for the local languages are permanently employed at the DoJCD, and they therefore have job security. In an economy such as South Africa's with intractable unemployment problem across all sectors, the foreign African court interpreters' concern about being casual for several years (for some more than eight years) needs to be addressed, whereas casual interpreters in other countries are likely to have other sustainable means of earning a livelihood. The excerpt, therefore, reveals a major failing on the part of the court interpreting authority in South Africa, especially given that most $(75 \%, \mathrm{~N}=23)$ of the participants (interpreters) are naturalised South Africans and would like to be treated like the South Africans interpreters of local languages.

The same failing can also be attributed to the fact that most of the interpreters used by the courts are not properly qualified for interpreting in the court. Although this is not a problem unique to South Africa (e.g., Berk-Seligson, 1990; Miguélez, 1999), it is only in South Africa that there is no emphasis on relevant minimum qualifications for a certified interpreter. The data regarding prior training, in-service training and self-sponsored training revealed that the only training the court interpreters could claim is the lingual aspect of training, and an insignificant percentage of the respondents claimed to have tertiary level qualifications. A small percentage of respondents also claimed to be studying (or to have studied) law. Apart from the fact that the percentage of the respondents that could be credited with these forms of training is very low, in the context of court interpreting, the amount of training they had received was not enough to equip the court interpreters with the requisite skills for quality interpreting. In the context of the argument that is being advanced in this study, this is a management problem. For example, the chief interpreters who are in charge of interpreting at the DoJCD admitted that it was necessary to have established minimum requirements to ensure good entry level interpreting but they stressed this has not been pursued vigorously. They pointed to several court interpreting diplomas and bachelor degrees at tertiary institutions across the country but admitted that these qualifications are not considered as essential in the recruitment of both foreign African interpreters and local interpreters. Consequently, the vexed question of terminology research will continue to dog the South African court interpreting practice for some time to come.

\subsection{Misunderstood Role of Interpreter}

There is a profound lack of understanding of the interpreter's role, and of what quality interpreting involves. This is evident from the actions of the other main actors in the courtrooms in this study. The issues that came to light in this regard concerned the ways these actors related with the interpreter, the accused or the plaintiff. In any social encounter where the question of fairness is paramount, conflicts of interest must be eschewed. In the case of court interpreting, this means interpreters should not have any form of relationship with the accused, plaintiff, magistrate, prosecutor, attorney and any other person having interest in the case-in order to be considered impartial and to pass strict tests of confidentiality.

Oftentimes, during my observation of court proceedings and during interviews with interpreters after court proceedings, the interpreters' conduct indicated a conflict of interest as there were several instances where the accused person was found mingling with the court interpreters. This led me to question the interpreters to find out about their awareness with regard to issues that constitute conflicts of interest. The data analysed shows that 55 per cent $(\mathrm{N}=17)$ did not see anything wrong with associating with the accused or the plaintiff and $45(\mathrm{~N}=14)$ per cent claimed they were aware it was wrong but said it was not an issue to their employer (the chief interpreters at the DoJCD). The chief interpreters, who are responsible for the interpreting affairs in the court, condemned such relationships but admitted they had not made any attempt to check if this was happening. Interpreters are supposed to be bound by strict rules of confidentiality. Hence, the way they conduct their lives must be above reproach so as not to give room for others to accuse them of having compromised some confidential information they are privy to. When such instances of interpreters associating with the accused persons or plaintiffs are seen by the accused persons or plaintiffs, or an attorney who has been having difficulty with interpreting, they are likely to conclude that the interpreter is working against their interests in the case. Such situations can also be grounds for an appeal, especially by an attorney who will stop at nothing to prove 
that the court interpreting system is not reliable and did not deliver justice to his/her client.

By virtue of their position in the justice system, interpreters are privy to confidential information. While associations of the kind mentioned above may not compromise such information, it will be difficult for the interpreter to refute culpability if such information gets into the wrong hands, or if an attorney they have mingled with is advantaged by receiving such information. Given the data mentioned above, the interpreters do not actually know what their responsibilities as interpreters are, and neither are they able to say whom they should refrain from associating with in order to avoid a conflict of interest.

A code of conduct drawn up in Australia which is very relevant to the issues being discussed here advises that the interpreters should see themselves in the context of message transfer from the SL to the TL speaker, and should not engage in advocacy, advice and guidance roles (AUSIT Code of Ethics \& Conduct 2012). To prevent this, the Australian code of ethics advises that "interpreters and translators provide an explanation of their role in line with this Code" of ethics to their clients and others they encounter regularly, such as magistrates, attorneys and prosecutors (AUSIT Code of Ethics and Conduct, 2012, p. 3).

Similarly, the magistrates, prosecutors and attorneys have superficial understandings of the responsibility of interpreters and what interpreting means in terms of the limitations faced by interpreters in their tasks. For example, a significant number of the prosecutors in this study $(\mathrm{N}=8)$ and attorneys $(\mathrm{N}=6)$ did not see anything wrong with interpreters mingling with the accused persons in and outside the court, and some prosecutors admitted that they were personal friends of some of the interpreters. Their response shows that they do not really understand the need for interpreters to remain impartial. Hence one of the prosecutors said:

Does it really matter? All I care about is for the interpreter to do his work. Who is his friend, who he sees outside the court or inside the court is not an issue. Interpreters help us when there is language issue.

It is necessary for prosecutors to demonstrate impeccable character in carrying out their duties, and interpreters must do the same if the integrity of the judicial process is to remain unassailable. Apart from the fact that misinterpretation by the interpreters can result in miscarriage of justice, instance where they decide to be partial can arise due to their association with the accused or any other person having an interest in the case. These facts were overlooked by a significant percentage of the prosecutors, magistrates and attorneys interviewed in this study. Similar issues were reported by Usadolo \& Kotze (2010). In their study, interpreters admitted that they did help accused persons by providing in the TL what they thought would be appropriate responses to questions asked by prosecutors, magistrates or attorneys. Inggs' (1998) study also provides instances of interpreters who admitted they carried out an advocacy role to the accused persons or plaintiffs and disregarded the fact that such a role is unethical.

Interpreters are there to interpret from SL into TL accurately for the magistrates, prosecutors and attorneys. While this is what is required from the interpreters given the sensitivity of court interpreting, the data in this study revealed a profound lack of understanding on the part of these judicial representatives of several challenges faced by interpreters. For example, from the responses provided by seven magistrates, nine attorneys and five prosecutors, there is a perception among them that interpreting is a mechanical and robotic process, as most of them believe that it is possible for an interpreter to provide word-for-word translations. Although the respondents cited in the example above could not give me an example to substantiate their claim that interpreting was a robotic process, their responses disregarded the influence of culture in interpreting. According to Liu (1994, p. 311), "National psychology and ideological inclination lead to differences in logical thinking and reasoning, and, consequently different responses". What Liu's assertion means is that even for two people using the same language, there are bound to be differences in the manner people from different culture speak. Hence, the belief that interpreting is a mechanical process may not result in quality interpreting as the interpreter needs to consider the culture of the SL and TL speakers and render what is appropriate to his/her client.

The principle of accuracy means that interpreting must be rendered faithfully, without altered information, but this is not entirely possible. Hence, Jacobsen remarks that assumptions of accuracy and completeness involve a disregard for issues such as language differences or cultural differences, or problems of ambiguity that may occur either from the accused person or the plaintiff or any other principals of the court. As indicated earlier, some words in African languages do not have any direct equivalents in English, and vice versa. Scholars have noted that in several instances, it is quite impossible to provide a word-for-word rendition from SL into TL, and any attempt to do that may result in a poorly handled interpreting assignment. When faced with such challenges, the ideal approach to interpreting is to ensure that the rendition given is a significant representation of intent and content of the SL or in the words of Nida (2004, p. 163), the "highest degree of approximation" should be rendered into the TL. In that way, language barriers and their associated cultural barriers are removed so that the 
accused person can participate fully in his/her own defence in the courtroom.

\subsection{Code-Switching, and Interpreting in the First Person and Third Person}

Code-switching (CS) is a common practice employed by interpreters and others such as prosecutors and attorneys in the courtroom. CS is the mixing or switching of two or more languages in one sentence or between sentences. CS, as defined by Bokamba $(1988$, p. 24), is "the embedding or mixing of words, phrases, and sentences from two codes within the same speech event across sentence boundaries". Today, it is a common sociolinguistic phenomenon to see people mixing or switching their indigenous languages with those of their erstwhile colonisers. Communication in courtrooms is not spared this phenomenon. CS is a common speech pattern of people in multilingual communities. It is common to hear the prosecutor embedding isiZulu expressions such as "woza lapha baba" (Come here, father/old man) in an English conversation. Figures and colours which can easily be expressed in both the SL and TL are frequently code-switched. This is a common occurrence when the SL being rendered into the TL by the court interpreter is from the magistrate, prosecutors and attorneys. Some frequently code-switched words are names of months, and names of departments or government offices, such as Johannesburg City Council. These words have common equivalents in local languages, especially in Igbo, Yoruba, Edo, \& Shona, according to the court interpreters whose working languages are these languages.

Although some scholars can point to the advantages of CS, the nature of communication in the court demands that the court interpreter convey the complete meaning of the speaker's message as it is. CS, as used by the court interpreters indicates what Auer (1988, p. 195) refers to as the display of "an imbalanced bilingual competence" and it negates Usadolo \& Kotze's (2015) view about the need for a balanced bilingualism on the part of court interpreters. Although balanced bilingualism is not enough to ensure accurate and quality interpreting, as indicated earlier, the notion of an imbalanced bilingual competence, as revealed by the use of CS by the court interpreters in this study, is an added concern regarding the need for quality interpreting in the courtroom.

One interesting fact regarding code-switching revealed in this study is that it is not true that all the accused persons or witnesses requesting court interpreters do not understand English, the common language used in the court. My observation of courtroom proceedings shows that some of the accused persons or witnesses can speak English. This is usually in the form of English as an embedded language in addition to their mother tongue (the matrix language). They use English as an embedded part of their sentences and with a level of proficiency the magistrate or the prosecutor can easily understand. In magistrates' courts, one often sees the magistrates taking over the role of the prosecutors, and in one such instance in Hilbrow District Magistrate Court, Court 1, the accused responded in CS form to the questions asked by the magistrates without waiting for the interpreter to interpret what the magistrate had said. This shows the accused understood English. In this case, and in other similar cases witnessed in the courtrooms, the interpreters would however continue interpreting, not minding the fact that the accused had already responded to the questions asked.

This also manifests in the way some of the accused persons would react to what the prosecutors or the magistrates had said before the interpreter interpreted what had been said. A number of accused persons and witnesses, who were either on bail or had been discharged, were interviewed about this phenomenon. In these interviews, some of the accused persons and witnesses admitted that the use of English in the form of writing and speaking was not their problem, but that they were uncertain about the level of proficiency required in the courtroom situation, and hence they had to request the services of an interpreter. One of the accused persons said he had no problem with the use of English in the courtroom, but he opted to use the services of court interpreters, "because these people depend on us to survive". In other words, even though he understood English, he preferred to use the services of a court interpreter, as that enabled the interpreter to earn more money. The foreign African interpreters who were respondents in this study were all casual interpreters paid at the end of the month based on the numbers of interpreting assignments they handled. In other words, the more interpreting assignments they handled, the more they would get in the form of remuneration at the end of the month. In this instance, the decision by the accused to request the services of an interpreter even when writing and speaking is not his problem seems to point to some measure of collusion between him and the interpreter. Importantly, it reveals a disturbing phenomenon in court interpreting in South Africa characterised by lack of regulatory authority. It also goes to explain why the simple rule of interpreting in the first person, discussed in the next paragraph, is not adhered to.

The use of the first person is regarded as the most efficient and effective way of interpreting in the court, as it allows the interpreter to directly state what the speaker has said (Krikke \& Besiktaslian, 2005). In other words, it allows the SL message to be transferred in direct speech as if it had originated with the original speaker 
(Moeketsi, 2000). In this way, the interpreter ensures that the SL message is conveyed in the same way as it has been spoken. This causes the court interpreter to be unobtrusive and invisible in the court, according to Moeketsi (2000). However, what happens in actual fact is that most foreign African court interpreters use the third person in the courtroom, as the discussion below exemplifies.

In my observation of court proceedings, an Igbo interpreter assumed that the accused person understood what the magistrate had said. She therefore continued by asking the accused in standard Igbo "Ighota ife okwuru?" (Do you understand what he said?), to which the accused responded "yes". She nevertheless continued to interpret (possibly for the record) in the third person by saying, "He said your case has been postponed to ..." instead of saying "The case has been postponed to ....". In cases where the accused had pleaded guilty, it was a common occurrence that both the foreign African court interpreters and the South African court interpreters did not care about professional conduct or practice. They would assume that not much is in contestation and so caution is not warranted. Consequently, instead of the interpreter interpreting the accused's statement in the first person as: "I plead guilty", some of them relayed the statement by saying: "He pleads guilty", after sight translating the charge to which the accused had pleaded guilty. In such cases, the interpreters continued with summary interpreting, especially during the sentencing stage.

It was common also to hear the court interpreters interpreting any Nguni family language using the third person, such as $u t h i$ (he/she said), several times when they were relaying what the prosecutors, attorneys or the magistrates had said to the accused or witnesses.

\section{Discussion and Conclusion}

Court interpreting is a sensitive communicative act because the fair dispensation of justice-in a situation where one or more of the accused or plaintiffs are linguistically handicapped-depends on the rendition of the interpreter. As pointed out in this study, it requires a competent interpreter in a properly managed court interpreting system to ensure that those who are linguistically handicapped are given a voice to express themselves in the court.

Given the data analysed in this study about the notion of equivalence in interpreting, it is imperative that interpreters have ways of mitigating its attendant problems. In the context of this study, the chief interpreters will play a major role in ensuring that the interpreters are committed to more research and learning to mitigate problem of equivalent terms or phrases. The chief interpreters have to provide appropriate supervisory authority which may be in the form 'member checking' where an interpreter with sufficient knowledge of both languages (SL and TL) is assigned to monitor a colleague. This will be done with a view to recommending areas for improvement and training to the interpreting authority.

The analysis also revealed some organisational factors - a perceived lack of organisational and leadership support-resulting in a host of negative work outcomes such as lack of commitment and job dissatisfaction. These poor work outcomes are caused by a perceived feeling of differential treatment by the majority of foreign African interpreters. They cited the fact that the local language interpreters are employed as permanent interpreters by the DoJCD, which gives them some measure of job security, unlike the foreign African interpreters who are hired on a casual basis. Significant numbers $(\mathrm{N}=21)$ of these foreign African interpreters had been working as casual interpreters for 6 to 10 years and were feeling detached from their organisation because of the perceived differential treatment. According to Maertz, Griffeth, Campbell, \& Allen (2007) when employees perceive a lack of support from their organisations and their supervisors, they will be less committed to their job, owing to lack of job satisfaction. March \& Simon's (1959) theory of organizational equilibrium supports this argument. They suggest that employees' decisions to remain working in any organization are a result of the balance between what they expect from the organisation and what they will contribute to the organisation.

There is another issue which I will characterise as poor team membership. In a multicultural society, interpreters' services are required in many forms of communicative encounters. Hence in court, interpreters are important members of a team that engages in verbal duelling to examine opposing arguments before judgement is delivered. The response of the prosecutor who said: "... Who is his friend, who he sees outside the court or inside the court is not an issue. Interpreters help us when there is language issue" negates this view. The interpreters are not considered a part of the team, consequently leaving them out of the support system such team does access in furtherance of the job. Support mechanism in this case can be further training regarding the team role and what other team members jobs entail.

The contribution of other principals, besides interpreters, to interpreting success is of concern given the data analysed in this study. That data discussed shows that the magistrate, the prosecutor, and the attorney have superficial understandings of the role of interpreters in the judicial process. Hence impartial conduct on the part 
of interpreters is considered irrelevant to the judicial process. Other challenges that also affect interpreting quality, such as codeswitching, which is a feature of multicultural societies, were discussed. Finally the unprofessional attitudes of some the interpreters in terms of interpreting in third person instead of first person were pointed out.

A valuable line of intervention to take, therefore, would involve educating the interpreters, magistrates, prosecutors and attorneys regarding interpreting practices. This intervention would highlight some fundamentals of interpreting practices such as the need for the unobtrusive presence of interpreters in the courtrooms. There is less research focusing on this aspect of interpreting. Thus future research in the South African context must investigate this as well as ascertain in depth what magistrates, prosecutors and attorneys know about interpreting practice. Such study may help in developing awareness of the trio regarding interpreting practices. It will also sensitise them towards issues such as role boundaries, confidentiality, and conflicts of interest, especially in understanding them as issues that matter to all involved in the discharge of justice.

Given the size of the sample in this study, ascertaining the extent to which the findings discussed are reflective of the norms and actual behaviours of interpreters across South Africa is problematic. However, this study has provided a platform to consider the issues discussed, and to consider related issues on a wider scale in order to ascertain if the findings apply more generally. As such, future research regarding these topics should be carried out with a larger sample across magistrate courts in the nine provinces of South Africa.

\section{References}

Auer, J. C. P. (1988). A conversation analytic approach to code-switching and transfer. In M. Heller (Ed.), Code-switching: Anthropological and Sociolinguistic perspectives. Berlin: Mouton de Gruyter. http://dx.doi.org/10.1515/9783110849615.187

Berk-Seligson, S. (1990). The Bilingual Courtroom: Court Interpreter in the Judicial Process. Chicago: Chicago University Press.

Bokamba, E. (1988). Codemixing, language variation and linguistic theory: Evidence from Bantu languages. Lingua, 76, 21-62. http://dx.doi.org/10.1016/0024-3841(88)90017-4

Frishberg, N. (1986). Interpreting: An Introduction. Silver Spring, M D: Registry of Interpreters for the Deaf.

González, R. D., Vásquez, V. F., \& Mikkelson, H. (1991). Fundamentals of Court Interpretation: Theory, Policy and Practice. Durham, NC: Carolina Academic Press.

Hewitt, W. (1995). Model Code of Professional Responsibility for Interpreters in the Judiciary. The Judges' Journal, 34, 30.

Inggs, J. (1998). Current developments in court interpreter training in South Africa. Proteus, 7.

Jacobsen, B. (2007). Additions in court interpreting. Retrieved from http://www.criticallink.org/journalscl2/5.doc

Khoon, W. F. (1990). Court interpreting in a multiracial society - the Malaysian experience. In D. Bowen \& M. Bowen (Eds.), Interpreting-Yesterday, Today and Tomorrow (pp. 108-116). Binghamton: State University of New York. http://dx.doi.org/10.1075/ata.iv.19kho

Krikke, A., \& Besiktaslian, M. (2005). Effective use of interpreters. In H. Keijzer-Hambooy \& W. J. Gasile (Eds.), Aequilibrium: Instruments for Lifting Language Barrier in Intercultural Legal Proceedings. Utrecht: ITV Hogeschool voor Tolken en Vertalen.

Lebese, S. (2014). Do justice to court interpreters in South Africa. Stellenbosch Papers in Linguistics Plus, 43, 183-208. http://dx.doi.org/10.5842/43-0-179

Maertz, C. P., Griffeth, R. W., Campbell, N. S., \& Allen, D. G. (2007). The effects of perceived organizational support and perceived supervisor support on employee turnover. Journal of Organisational Behaviour, 28, 1059-1075. http://dx.doi.org/10.1002/job.472

March, J., \& Simon, H. A. (1959). Organisations. New York: Wiley Press.

Miguélez, C. (1999). Current Issues in Court Interpreting: Spain, A Case Study. Proteus, 8.

Mikkelson, H. (1995). On the horns of a dilemma: Accuracy vs. brevity in the use of legal terms by court interpreters. Translation and the Law (pp. 201-218). Amsterdam: John Benjamins. http://dx.doi.org/10.1075/ata.viii.14mik

Mikkelson, H. (1999). Verbatim interpretation: an oxymoron. Retrieved from http://www.acebo.com.papers/verbatim.htm 
Moeketsi, R. (1999). Redefining the role of the South African court interpreter. Proteus, 8, 3-4.

Moeketsi, R. (2000). The do's and don't's in court interpreting: A functional approach to a professional code. Language Matters, 12, 222-242. http://dx.doi.org/10.1080/10228190008566166

Moeketsi, R., \& Mollema, N. (2008). Towards perfect practice in South African court interpreting: A quality assurance and quality management model. International Journal of Speech Language and the Law, 13, 76-88. http://dx.doi.org/10.1558/s1l.2006.13.1.76

Moeketsi, R., \& Wallmach, K. (2005). From sphaza to makoya!: A BA degree for court interpreters in South Africa. The International Journal of Speech, Language and the Law, 12, 77-108.

Nida, E. (2004). Principles of correspondence. In L. Venuti (Ed.), The translation studies Reader (pp. 153-167). New York: Routledge.

Seleskovitch, D. (1978). Interpreting for International Conferences. Washington, D. C.: Pen and Booth.

Usadolo, S. E., \& Kotzẹ, E. (2010). Conflicts of interest in court interpreting in South Africa: A case study of foreign African court interpreters. In A. Arnall \& U. Ozolins (Eds.), Proceedings of the 'Synergise' Biennial National Conference of the Australian Institute of Interpreters and Translators (pp. 93-109). New Castle upon Tyne: Cambridge Scholars Publishing.

Usadolo, S. E., \& Kotze, E. (2014). Some interlingual communicative challenges for foreign African interpreters in South African courtrooms. Stellenbosch Papers in Linguistics Plus, 43, 345-357. http://dx.doi.org/10.5842/43-0-184

Usadolo, S. E., \& Kotze, E. (2015). Communicative challenges of interpreting in cross-border languages in South African courtrooms. South African Journal of African Languages, 35, 57-65. http://dx.doi.org/10.1080/02572117.2015.1056464

Walliman, N. (2006). Social Research Methods. London: Sage Publications. http://dx.doi.org/10.4135/9781849209939

\section{Copyrights}

Copyright for this article is retained by the author(s), with first publication rights granted to the journal.

This is an open-access article distributed under the terms and conditions of the Creative Commons Attribution license (http://creativecommons.org/licenses/by/3.0/). 